Article

\title{
The Samaritans during the Hasmonean Period: The Affirmation of a Discrete Identity?
}

\author{
Jonathan Bourgel \\ Department of theology and religious studies, Laval University, Québec City, QC G1V 0A6, Canada; \\ jonathan.bourgel@ftsr.ulaval.ca
}

Received: 14 October 2019; Accepted: 8 November 2019; Published: 14 November 2019

\begin{abstract}
The Hasmonean period (167-63 BCE) is increasingly seen in current scholarship as formative for Samaritan identity and, in particular, as the moment when the Samaritans emerged as a self-contained group separate from the Jews. The first aim of this paper is to give an overview of the condition of the Samaritans during this period. In largely chronological order, the first part of the article discusses the situation of the Samaritans on the eve of the Hasmonean revolt, at the outbreak of the uprising, and under the rule of the first Hasmoneans. The second aim is to review the commonly held causes of the emergence, at this time, of the Samaritans as a discrete community, such as, for instance, the destruction of the Samaritan temple, the production of the Samaritan Pentateuch and the appearance of anti-Samaritan polemics in Jewish literature. The paper concludes that the Hasmoneans' attitude toward the Samaritans cannot simply be seen as one of hatred and rejection as is generally assumed. Besides; although some of the historical processes beginning in the Hasmonean period had far-reaching implications for the parting of the ways between Jews and Samaritans; their immediate effects should not be overstated.
\end{abstract}

Keywords: Samaritans; Samaritan identity; Hasmonean period; Jewish-Samaritan relations

The constitution of the Samaritans as a discrete community is generally seen as the outcome of a process of mutual estrangement between them and the Jews. While a great deal has been written in the attempt to delineate the circumstances of their "parting of the ways," most scholars now consider that this development was not the result of a single occurrence, a schism so to speak, but rather a gradual historical process extending over several centuries. ${ }^{1}$ In this regard, the Hasmonean period (167-63 BCE), during which an independent Jewish kingdom was established in the land of Israel, is commonly regarded as a decisive and formative moment, if not a definitive one, in the emergence of a self-contained Samaritan identity. ${ }^{2}$

The aim of this paper is to give an outline of the situation of the Samaritans and their relations with the Jews during this period, and to review the major causes identified in the scholarship for the formation of a distinct Samaritan identity at that time. In the course of the discussion, it will be argued that the attitude of the Hasmoneans toward the Samaritans cannot simply be seen as one of hatred and rejection as is generally assumed, and that evidence for the constitution of the Samaritans at that time as a group utterly separated from the Jews should not be overstated.

1 An early advocate of this view was James D. Purvis (Purvis 1968, p. 5), according to whom: “The so-called Samaritan schism, or withdrawal from the mainstream of Judaism, was not so much an event as a process-a process extending over several centuries and involving a series of events which eventually brought about estrangement between the two communities." See also (Coggins 1975, p. 163; Hjelm 2004, p. 15; Pummer 2007, p. 247).

2 See inter alia (Cross 1966, p. 211; Purvis 1968, p. 118; Mor 1989, p. 18; Hjelm 2004, p. 29; Schorch 2005, p. 10; Pummer 2007, p. 248). Others argue for dating the parting of the ways between Jews and Samaritans to the first centuries CE. See, for instance (Coggins 1975, p. 151; Crown 1991). 


\section{Overview of the Situation of the Samaritans on the Eve of the Hasmonean revolt}

\subsection{In the Land of Israel}

It is difficult to get a clear picture of the situation of the Samaritans on the eve of the Hasmonean revolt. It should first be recalled that the political context at the turn of the second century BCE was marked by the passing of control of the land of Israel from the Ptolemies to the Seleucids, as a result of Antiochus III's victory at the Battle of Panion (200 BC).

Specific information on the Samaritans at this time derives mainly from the Jewish historian Flavius Josephus (37-ca 100 CE), whose stance on the Samaritan community is usually considered to be tainted with hostility and antagonism. ${ }^{3}$ Josephus refers to the city of Shechem in the Hellenistic period as the metropolis of the Samaritans and a place of refuge for Jewish apostates (Ant 11.340; 346). He also reports that the Samaritans had their own temple on the nearby Mt. Gerizim. It was modelled on the temple in Jerusalem, at the initiative of the governor of Samaria, Sanballat, with the permission of Alexander the Great (ca. 332 BCE; Ant. 11.302-25; 13.256). Sanballat protected renegade Jewish priests (expelled from Jerusalem for refusing to divorce their foreign wives), establishing them as priests in the Gerizim temple. ${ }^{4}$ Some scholars, however, consider this account to be an elaboration of Neh. 13:28, according to which Nehemiah (mid-fifth century BCE) expelled one of the grandsons of the high priest Eliashib because he was married to the daughter of Sanballat the Horonite. ${ }^{5}$

The archaeological digs carried out by Yitzhak Magen from 1982 to 2006 have confirmed the existence of a Samaritan temple on Mt. Gerizim although, so far, only its temenos (surrounding precinct) has been unearthed. In contradistinction to the data provided by Josephus, Magen dates the erection of the Samaritan sanctuary not to the time of Alexander the Great, but to the Persian period (mid-fifth century BCE); later on, it underwent a second phase of construction during the Hellenistic period (early second century BCE). Moreover, the remains of a large city that surrounded the sacred precinct from the late fourth century onward have been unearthed. Magen considers that this urban center "reached its maximal size in the second century BCE, with an overall area of about 400 dunams (800 $\mathrm{m}$ long and some $500 \mathrm{~m}$ wide), becoming the capital of the Samaritan people and its religious and cultic center." 6 According to Magen's own estimates, at its peak, the city numbered about ten thousands inhabitants. Also noteworthy is the discovery on Mount Gerizim of hundreds of inscriptions, the vast majority of which are votive inscriptions in Aramaic dating to the Hellenistic period. ${ }^{7}$ These documents have revealed some of the donors' places of residence, including Shechem (שכם), ' Avarta or ${ }^{c}$ Awarta (עבר]תא], roughly six km south of Shechem) and Kfar Haggai (כפר חגי, probably modern Hajja, about $14 \mathrm{~km}$ west of Shechem). Interestingly enough, some of the donors apparently came from the city of Samaria (שמריi), at the time an important Hellenistic city whose inhabitants were mostly the descendants of Macedonian settlers, ${ }^{9}$ and which was the seat of a temple devoted to the cult of the Egyptian deities Isis and Serapis. ${ }^{10}$ Reinhard Pummer has inferred hence that, in spite of its strongly Hellenistic character, Samaria was still inhabited by "Yahwisitic Samarians" in the second century BCE. 11

\footnotetext{
See for instance (Cohen 1979, pp. 149-50; Coggins 1987, p. 271; Feldman 1996). For the opposite view, see (Egger 1991). See for instance (Kippenberg 1971, p. 52).

I agree with Jan Dušek that, in all likelihood, "Josèphe a transféré le personnage de Sanballat du Ve s. av. J.-C. au IVe s. av. J.-C." (Dušek 2007, pp. 540-41). See also e.g., (Kippenberg 1971, p. 52). For a different opinion see for instance: (Vanderkam 2004, p. 76).

6 (Magen et al. 2004, p. 1). On the Samaritan sanctuary and its dating, see (Magen 2007; 2008b, pp. 97-205). On the Hellenistic city nearby the Samaritan sanctuary on Mt. Gerizim, see (Magen 2008b, pp. 3-93).

7 On these inscriptions, see (Magen et al. 2004; Dušek 2012; de Hemmer Gudme 2013).

See (Magen et al. 2004, pp. 28-30).

See for instance (Pummer 2009, p. 204; Eshel 2012, p. 517; Knoppers 2013, p. 173).

10 See (Magness 2001).

1 See (Pummer 2018, p. 70).
} 


\subsection{Evidence for Diasporic Samaritan Communities in the Second Century BCE}

We know from various sources of the existence of Samaritan communities outside the land of Israel during the Hellenistic period. In this respect, the so-called Samaritan inscriptions from Delos are of great importance. These are two honorific dedications in Greek engraved on marble stelae. The dedicators present themselves as "the Israelites on Delos who make offerings

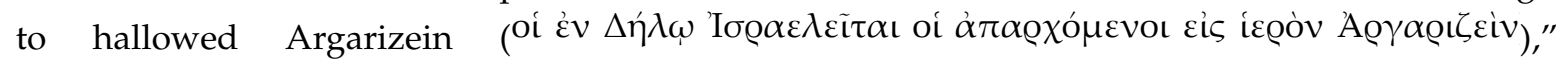
and "the Israelites who make offerings to hallowed, consecrated Argarizein

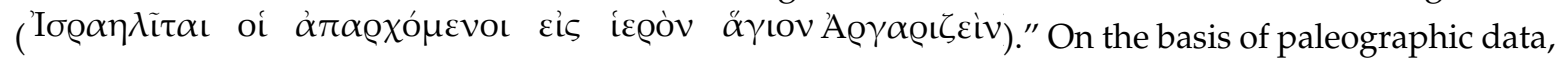
the first stela has been dated to between 150 and $50 \mathrm{BCE}$, and the second to between 250 and 175 BCE. ${ }^{12}$ As has been widely acknowledged, declarations of belonging to the people of Israel and belief in the sanctity of Mount Gerizim (Argarizein) were fundamental to Samaritan identity. ${ }^{13}$ We therefore have evidence for the presence of a Samaritan community on the island of Delos at least between the third and first centuries BCE.

It is well known that a Jewish community was established on the island at that time (1 Macc 15,23; Ant 14:213-216, 231-232). Interestingly enough, the Samaritan stelae were found some ninety meters north of a second or first century BCE building (GD 80) discovered in 1912-13 by André Plassart and identified by him as a synagogue. ${ }^{14}$ Philippe Bruneau has inferred from this that Delian Jews and Samaritans lived together within a Jewish enclave ("juiverie"). ${ }^{15}$ In his opinion, the formation of this enclave is to be ascribed either to the local authorities who controlled the settlement of foreign groups on the island or to the Jews and Samaritans themselves who wanted to live in close proximity on account of some sense of communal identity. In this respect, it has been pointed out that the self-identification of the authors of the Delos inscriptions as "the Israelites who make offerings to Mount Gerizim" supposes that from their standpoint an Israelite was not essentially a Gerizim worshipper; the implication of this could be that they regarded the Jews as being "the Israelites who make offerings to Jerusalem."16

Also noteworthy are Josephus' accounts referring to the presence of Samaritans in Ptolemaic Egypt (Ant 12.7-10; 13.74-79). ${ }^{17}$ Josephus seems to ascribe the origins of this Samaritan diaspora community to Ptolemy I Soter (304-282 BCE) who, "after taking many captives both from the hill country of Judaea and the district round Jerusalem and from Samaria and those on Garizein, brought them all to Egypt and settled them there" (Ant 12:7).$^{18}$ Josephus adds that the descendants of these Jewish and Samaritan settlers were in a violent dispute that they brought before the Egyptian king (Ptolemy VI Philometor; 180-145 BCE); it concerned the legitimacy of their respective sanctuaries. Eventually, the Jewish representatives succeeded in convincing the king that only the Temple of Jerusalem had been erected in accordance with the laws of Moses. These accounts raise not a few difficulties, the most important of which is whether they refer to one or two distinct events. They have also been questioned on the ground that they abound in "literary motifs and legends." ${ }^{19}$ Most scholars, however, tend to accept their general historical framework. ${ }^{20}$

12 See (Bruneau 1982). This dating has been generally accepted; see for instance (Kraabel 1984). L. Michael White has ascribed the first inscription to after, and the second to before, 166 BCE (White 1987, pp. 144-45).

13 See among others (Pummer 2009, p. 17; Kartveit 2014, p. 467).

14 (Plassart 1914). The identification of GD 80 as a synagogue has been supported by several later scholars including (Bruneau 1982, p. 467; Trümper 2004, pp. 513-98). For a different opinion, see (Mazur 1935, pp. 21-22) and more recently (Matassa 2007).

15 (Bruneau 1982, pp. 502-4).

16 See (Dušek 2012, p. 77; Bourgel 2017, pp. 400-2).

17 For discussions of these accounts, see for instance (Coggins 1987, pp. 263-64; Pummer 2009, pp. 179-99).

18 Trans. Ralph Marcus (LCL 365; 1943, p. 5).

19 See (Isser 1976, p. 9).

20 See for instance (Kartveit 2009a, p. 126; Eshel 2012, p. 519). Bruce W. Hall has adopted a more cautious line, alleging that: "while it is quite probable that in hellenistic times Egyptian Jews and Samaritans disputed about the relative merits 


\subsection{Early Evidence for Jewish Anti-Samaritan Hostility? The Case of Ben Sira 50:25-26}

It has been proposed that further evidence for tensions between Jews and Samaritans in the early second century BCE can been found in the Book of Ben Sira. ${ }^{21}$ This work was composed in Hebrew ca $180 \mathrm{BCE}$, and was later translated into Greek around the years 132-117 BCE. ${ }^{22}$ The bulk of the discussion bears on the interpretation of Sir 50: 25-26, whose Hebrew version reads:

Two nations my soul detests, and the third is not even a people (והשלישית איננו עם):

Those who live in Seir, and the Philistines, and the foolish nation that live in Shechem (וגוי נבל הדר בשכם וגוי) (NRSA).

Many have assumed that the "foolish people (גוי נבל)", against who Ben Sira voiced his hatred, are to be identified with the Samaritans. ${ }^{23}$ This stance derives from the above-mentioned statement of Josephus that Shechem was the city of the Samaritans at the time of Alexander the Great (Ant 11:340) and from an analogy with Gen 34:7 where Shechem, Dinah's rapist, is reported to have committed a "נבלה (an outrageous thing)" against Israel. Although this interpretation is not entirely without credibility, one should bear in mind with Peter Van der Horst and Reinhard Pummer that not every mention of Shechem in ancient literature is necessarily related to the Samaritans. In fact, it could also be that Sir 50:25-26 refers to the "non-Samaritan inhabitants of Shechem," ${ }^{24}$ for instance the "Sidonians in Shechem ( $\left.\tau \widetilde{\omega} \vee \varepsilon ่ v \sum \iota \kappa^{\prime} \mu \mathrm{o} \varsigma \Sigma \iota \delta \omega v i \omega v\right)$ " mentioned by Josephus in several passage s (Ant 11:340-347; 12:257-264). ${ }^{25}$ In this respect, the existence of inscriptions from Mt. Gerizim bearing Greek and Arabic names may be evidence that other population groups lived in the area. ${ }^{26}$ Likewise, not every use of

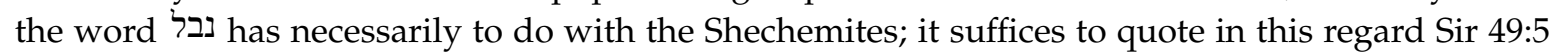
where the Babylonians are called a "foolish foreign nation (גוי נבל נכרי)."27 Furthermore, Pummer has rightly stressed that the city at the top of Mt. Gerizim, rather than Schechem, was the metropolis of the Samaritans in the Hellenistic period. ${ }^{28}$ Therefore, caution should be applied in too readily considering Sir 50:25-26 as a polemic against the Samaritans.

\section{The Samaritans at the Outbreak of the Hasmonean Revolt}

\subsection{Antiochus IV's Decrees against Judaism}

The ascent of Antiochus IV Epiphanes (ca 215-164 BCE) to the Seleucid throne in 175 BCE was to have lasting effects on the situation in the land of Israel. Soon after his accession, Antiochus was called upon to settle a dispute between the Jerusalem high priest, Onias III, and his brother Jason. The latter eventually obtained the high priesthood by offering a substantial bribe to Antiochus and by promising support in the Hellenization of the Jerusalemites (174 BCE; 2 Macc. 4:7-10). But three years later, Jason was displaced by Menalaus, not of Zadokite high priestly lineage, who offered Antiochus a greater bribe (2 Macc. 4:24). In 168 BCE, while Antiochus was campaigning in Egypt, a rumor spread throughout the land of Israel that he had been killed. On hearing this, Jason attacked his rival Menelaus in Jerusalem (2 Macc. 5:5). In reaction, Antiochus sent his army against the city, slaughtered its population, looted the Temple treasures and restored Menelaus (2 Macc. 5:11-21).

of Jerusalem and Mount Gerizim, we have no means of determining the historical basis of this particular narrative," (Hall 1987, p. 293).

21 See e.g., (Kippenberg 1971, p. 74; Marttila 2012, p. 210).

22 See (Sauer 2000, p. 22; Gilbert 2008, p. 7; Calduch-Benages 2008, p. 133).

23 See among others (Purvis 1965; Skehan and DiLella 1987, p. 558; Kartveit 2009a, pp. 140-48; Marttila 2012, pp. 206-15).

4 (Van der Horst 2003, p. 32; Pummer 2009, p. 12; 2016, pp. 47-50).

(Pummer 2016, p. 86). On the "Sidonians in Shechem," see below.

(Dušek 2012, p. 104).

7 See (Bourgel 2017, p. 386).

8 (Pummer 2009, p. 12). 
In 2 Maccabees 5:22-23 29 we find data of prime importance to the present discussion; this passage depicts the situation following the plunder of the Jerusalem Temple and Antiochus' departure to Antioch (summer 168 BCE):

He (sc. Antiochus) went so far as to leave officials in charge of maltreating our race ( $\tau \grave{\text { ò }}$

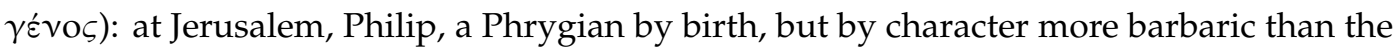
man who appointed him; and at Mount Gerizim, Andronikos; and in addition, Menelaus, who was worse than the others inasmuch as he lorded it over his compatriots. ${ }^{30}$

While the narrative context makes it clear that Antiochus assigned Philip of Phrygia to be governor of Jerusalem in order to secure his control over the city, the grounds for the appointment of Andronikos as governor at Mount Gerizim remain unexplained, (except the general accusation that Antiochus sought to maltreat the Jewish "race"). Nothing seems to indicate that the Samaritan worshippers at Mount Gerizim had been involved one way or another in the uprising against Menelaus in Jerusalem. Menachem Mor has wondered whether, just as in Jerusalem, the Jewish population was divided between proponents and opponents of Hellenism, so was the situation among the Samaritans at Mount Gerizim. Thus, prompted by the false rumor that Antiochus IV had been killed in Egypt, the Samaritan conservatives would have revolted to gain control over the Gerizim temple. ${ }^{31}$ Stressing that the process of Hellenization was very complex, Leister L. Grabbe has called for great caution in postulating a clear-cut dichotomy between "Hellenized" and "faithful" Jews, and in drawing an analogy in this matter between Jerusalem and Shechem. ${ }^{32}$ In the absence of further information, it could alternatively be suggested that the appointment of Andronikos at Mount Gerizim was a preventive measure rather than a reactive one.

In any event, it is noteworthy that the Yahweh worshippers on Mount Gerizim and in Jerusalem were put under the same restrictions. This raises the question of whether the Seleucid authorities made any distinction between Jews and Samaritans. No less remarkable is that the author of 2 Macc. 5:22-23 himself explicitly recognizes the two groups as belonging to the same "race," the Jewish people. ${ }^{33}$

The same can be said of 2 Macc. 6:1-2, which describes the beginning of the persecution against Jews and Judaism initiated by Antiochus in late $167 \mathrm{BCE}$ :

Not long thereafter, the king sent Geron the Athenian to compel the Jews (

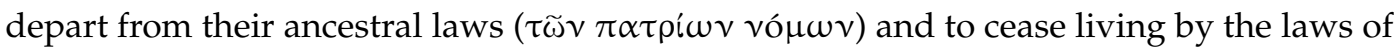
God. He was also to defile both the temple in Jerusalem and the temple on Mount Gerizim and to proclaim the former to be the temple of Zeus Olympios and the latter (in accordance

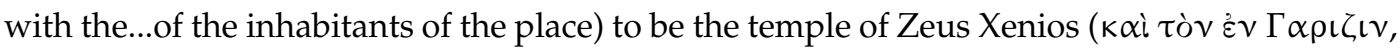

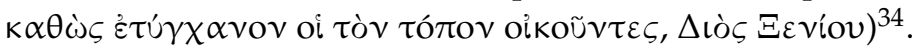

Here again, the category of Jews includes both the Yahweh worshippers in Jerusalem and on Mt. Gerizim. However, the depiction of the Samaritans in this account remains a matter of controversy,

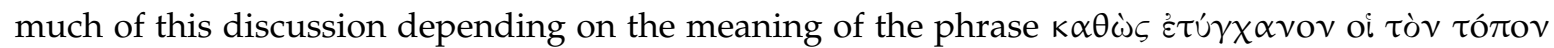

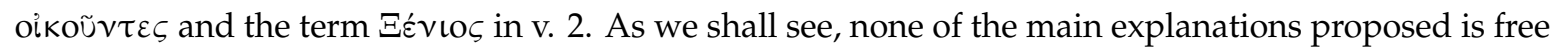
of difficulties.

292 Maccabees (2:23) describes itself as an epitome of Jason of Cyrene's lost five-volume work. Jason's original writings are usually dated to the first Hasmonaean generation, whereas the time of composition of its abridgement has been variously dated to the period between the rule of John Hyrcanus (134-104 BCE) and the conquest of Judea by Pompey (63 BCE). 2 Maccabees depicts the Jewish revolt against Antiochus IV Epiphanes from its beginning until the overthrow of the Seleucid general Nicanor (161 BCE). On the Second Book of Maccabees, see (Goldstein 1983, pp. 3-188; Schwartz 2008, pp. 3-126; Babota 2014, pp. 15-20).

30 Trans. (Goldstein 1983, p. 245).

31 (Mor 2003, pp. 104-5).

32 (Grabbe 2002, pp. 214-16).

(Goldstein 1983, p. 261; Schwartz 2008, p. 264; Doran 2012, p. 229).

Trans. (Goldstein 1983, p. 268). 


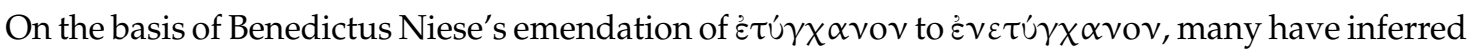
that the Mt. Gerizim temple was renamed after Zeus Xenios, at the request of the local inhabitants. ${ }^{35}$ This interpretation seemingly corresponds to the letter found in Josephus penned by people referring to themselves as the "Sidonians in Shechem" and asking Antiochus IV to allow that their temple be renamed after Zeus Hellenios (Ant 12:258-261; see below). There is, however, a noticeable discrepancy between the mention of Zeus Xenios in 2 Macc 6:2 and that of Zeus Hellenios in the letter of the "Sidonians in Shechem." Besides, as pointed out by Reinhard Pummer, Niese's emendation lacks any basis in the manuscript tradition. ${ }^{36}$ Furthermore, this interpretation would render incomprehensible Antiochus' dispatch of an emissary to "compel ( $\alpha \vee \alpha \gamma \kappa \dot{\alpha} \zeta \varepsilon \iota v)$ " the Jews to change the names of both temples, in Jerusalem and in Gerizim. As Robert Doran puts it: "Both the immediate and the larger context of 2 Macc 6:2 leads one to hold that the text should not be emended to align it with the Josephus correspondence." ${ }^{\prime 36}$ A second alternative explanation is that 2 Macc 6:2 is an allusion to the interpretation of 2 Kings 17:24-41 according to which the Samaritans were descended from the heathen colonists settled in Samaria by the Assyrians (late eighth century BCE) ${ }^{38}$ This proposition, though, stands in contrast to 2 Macc 5:22-23 and 6:1-2, which place the Gerizim and Jerusalem worshippers in the same category of Jews. A third alternative interpretation is that $\Delta$ iò $\Xi \varepsilon v i o v$ designates Zeus the Hospitable; accordingly, 2 Macc 6:2 would mean that the residents of the place (Mt. Gerizim) happened be hospitable like Zeus. ${ }^{39}$ Support for this reading could be found in a statement, ascribed to the second century BCE author commonly called Pseudo-Eupolemus, that the inhabitants of the city at the Gerizim temple received Abraham hospitably. ${ }^{40}$

Daniel R. Schwartz has raised objections to the two latter explanations: ${ }^{41}$

1. They imply that the readers of 2 Macc. had a thorough understanding of traditions related to Mt. Gerizim and the Samaritans, which is dubious.

2. They suppose that the renaming of the Mt. Gerizim temple suited the inhabitants of the place, whereas Antiochus' measures are portrayed as having been imposed against the will of the Yahweh worshippers in Jerusalem and on Mount Gerizim (we should note that this argument invalidates the first explanation mentioned above as well);

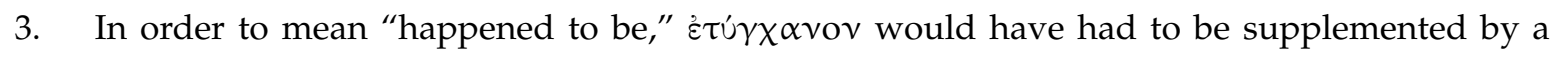
participle of a verb of being.

According to Schwartz the word in question is best explained as a secondary addition, most likely influenced by the text of the petition of the "Sidonians in Shechem" to Antiochus IV (Ant 12:258-261; see below). This proposition is appealing but it implies accepting Niese's emendation, which, as seen above, has some drawbacks.

In any event, it is most noteworthy that 2 Macc. $(5: 22-23 ; 6: 1-2)$ presents Jews and Samaritans as belonging to the Jewish people, and portrays them as co-victims of Antiochus' coercive measures.

\subsection{The "Sidonians in Shechem"}

As mentioned above, in his accounts of the persecution of the Jews by Antiochus, Josephus quotes a memorandum allegedly sent by the Samaritans to the Seleucid king (Ant 12:257-264). The authors of

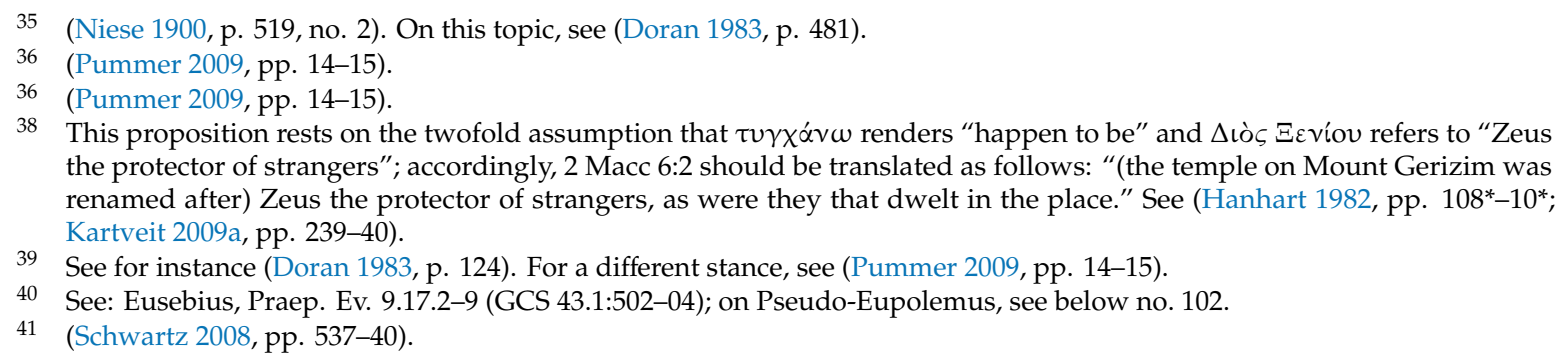




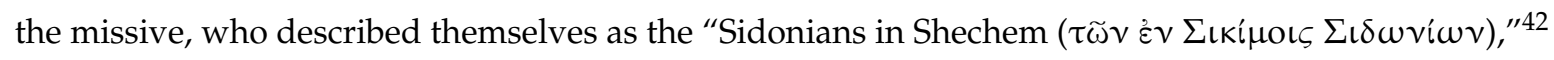
asked not to be persecuted as Jews on the grounds that they were of Sidonian stock, and that although they observed the Sabbath and "offered the appropriate sacrifices," they practiced different customs from the Jews. In addition, they demanded that the temple on Mount Gerizim be dedicated to Zeus Hellenios. Josephus, who identifies these Sidonians with the Samaritans, presents this letter as illustrating that the Samaritans were opportunists, deriving their apparently Jewish practices from mere superstition, to which they were after all loosely tied. This point is further verified by Antiochus' answer:

The Sidonians in Shechem ... have represented to us sitting in council with our friends that they are in no way concerned in the complaints brought against the Jews, but choose to live in accordance with Greek customs, we acquit them of these charges, and permit their temple to be known as that of Zeus Hellenios, as they have petitioned. ${ }^{43}$

Although the authenticity of these documents was long debated, their genuineness is now widely accepted in the wake of Elias Bickerman's demonstration in his 1937 publication "Un document relatif à la persecution d'Antiochos IV Épiphanes." ${ }^{44}$ These letters, however, raise several questions that are still under discussion, the most critical of which have to do with the identity of the "Sidonians in Shechem." Some scholars have assumed that they were reformist Hellenized Samaritans who sought to root themselves in Hellenistic culture. ${ }^{45}$ This proposal has been dismissed by, among others, Grabbe. In his opinion, the Samaritans as a whole, whose practices were very similar to those of the Jews, were-or threatened to become-the collateral victims of the upheaval in Jerusalem and Antiochus' subsequent attack on Judaism. Distancing themselves from the Jews was therefore likely to be an attempt "by diplomacy to have the decree lifted with regard to themselves." By acting so, they did not intend to forsake their religious practices, like the Sabbath, but meant rather to continue to observe them. ${ }^{46}$

For others, the "Sidonians in Shechem" were most likely members of a colony of Sidonians settled in Shechem. ${ }^{47}$ The existence of such colonies is attested to during the Hellenistic era in other cities of the land of Israel, like Marisa and Jamnia-on-the-Sea. ${ }^{48}$ In the same way that the Sidonians in Marisa adopted the cult of the local Idumean god Kos, ${ }^{49}$ it is likely that the "Sidonians in Shechem" to some extent adhered to the cult held in the temple on Mount Gerizim. If we were to accept this interpretation, we would have to conclude that the self-defined "Sidonians in Shechem" are to be clearly distinguished from the Samaritans (who identified themselves as Israelites). We should note, however, that the presence of a Sidonian colony in Shechem has been seriously questioned by Menachem Mor on the twofold ground that the Seleucid authorities would not have been unaware of its existence, and would have been most likely able to distinguish Sidonians from Jews. ${ }^{50}$

A further suggestion has been made by Richard Coggins that the Samaritans were called "Sidonians" simply because this name was tainted with pejorative connotations in certain passages of Isaiah $(23: 2 ; 4) .51$

\footnotetext{
42 The "Sidonians in Shechem" are first referred to in Ant 11:340-47. According to this account, the Samaritans, in an attempt to obtain Alexander the Great's favors, said that "they were Hebrews but were called the Sidonians of Shechem." But after Alexander asked them whether they were really Jews, they confessed that they were not.

43 Ant 12:262-64. Trans. Ralph Marcus (LCL 365; 1943, pp. 133-35).

44 See (Bickermann 1937; Isaac 1991; Dušek 2012, p. 103). For the opposite opinion, see (Rappaport 1990, pp. 386-93).

45 See (Mor 1989, p. 14; 2003, p. 120; Schwartz 1993).

46 (Grabbe 2002, p. 206).

47 See for instance (Isaac 1991; Dušek 2012, pp. 101-4).

48 On the Sidonian colonies at Marisa, see (Oren and Rappaport 1984).

49 Interestingly enough, the name of the god Kos appears in several theophoric names from the Sidonian tombs of Marisa. See (Peters et al. 1905, pp. 44-47, 54, 62-63).

50 (Mor 2003, p. 121).

51 (Coggins 1987, p. 266).
} 
It turns out thus that discussions of the petition of the "Sidonians in Shechem" to Antiochus can lead to very different conclusions, depending on whether one chooses to identify them as Samaritans in general, Samaritan Hellenistic reformers, or descendants of Phoenician colonists.

\section{The Samaritans under Hasmonean Rule}

\subsection{Under Jonathan (161-142 BCE)}

In reaction to Antiochus's decrees against Judaism, a rebellion broke out, with the Jewish rebels initially led by Matthias and his son Judas of the priestly Hasmonean family (167 BCE). But what began as a rebellion against religious persecution transformed in the course of time into a war of territorial expansion.

After the death of Judas (161 BCE), his brothers, Jonathan (161-142 BCE) and Simon (142-134 $\mathrm{BCE}$ ), took the lead in the struggle against the Seleucids. Exploiting dissension among the Seleucid rulers, and playing off one claimant to the crown against another, Jonathan gained religious authority and political control of additional lands. In $152 \mathrm{BCE}$, Alexander Balas, a pretender to the Seleucid throne, awarded Jonathan the high priesthood (1 Macc 10:20; Ant 13.45). In the same vein, in ca 145 BCE, Demetrius II Nicator (145-141 and 129-125 BCE), a new Seleucid ruler, officially annexed to Judea the three southern Samarian districts of Lydda (Lod), Aphairema (Ephraim) and Ramathaim (Rama) (1 Macc 11:34-36; Ant 13.127). Interestingly enough, the grant of these districts was supplemented by the award of exemption from all royal taxes for "all those who offer sacrifices in Jerusalem $(\pi \tilde{\alpha} \sigma \iota v$

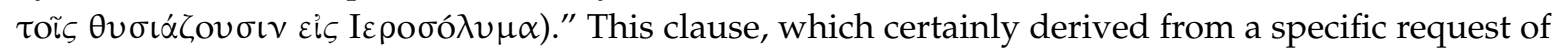
Jonathan (1 Macc 11:28), implies that those inhabitants of the three annexed districts who continued to bring sacrifices to the Samaritan temple on Mt. Gerizim were denied the exemptions. ${ }^{52}$ In other words, it seems that Jonathan used persuasion to convince those YHWH worshippers dwelling in the regions of Lydda, Aphairema and Ramathaim to recognize the Jerusalem temple as the only legitimate place of worship, and his high priest (Jonathan himself) as the only legitimate leadership. ${ }^{53}$ It is also likely that he could expect substantial economic benefit, if the offerings and tithes that had formerly been sent from the three southern Samarian districts to Mount Gerizim would henceforth be redirected to the Jerusalem temple. However, it must be stressed that the award of exemption from taxes for "those who offer sacrifices in Jerusalem" supposes in itself that offering sacrifices to the Gerizim temple, though discouraged, was not forbidden.

\subsection{Under John Hyrcanus (134-104 BCE)}

It is usually thought that it was not until the rule of Jonathan's brother, Simon that the Hasmonean state became independent of the Seleucid Kingdom (Josephus BJ 1.53; Ant. 13.211). The rule of Simon's son, John Hyrcanus, was to have tremendous consequences for the Samaritan community. According to Josephus' Jewish War (1.62), Hyrcanus launched a military campaign against the cities of Syria during the expedition of the Syrian ruler Antiochus Sidetes against the Medes (130 BCE). However, in Antiquities (13.254), Josephus reports that Hyrcanus began his campaign immediately upon learning of the death of Sidetes (129 BCE). This dating however, has been revised in the light of recent archaeological discoveries that indicate that Hyrcanus' territorial expeditions occurred toward the end of his reign, between the years 112/111-108/107 BCE. ${ }^{54}$

52 See (Goldstein 1983, pp. 432-33; Schwartz 1991, p. 56; Knoppers 2013, pp. 172-73).

53 In this respect it should be noted that, a few years earlier (152 BCE), Demetrius I Soter (161-150 BCE), in an attempt to win the support of Jonathan, assured him that the dwellers of the three Samarian "nomes" would recognize no other authority than that of the Jerusalem high priest (i.e., Jonathan; 1 Macc 10:38). It is likely that those areas were already militarily controlled by Jonathan and his followers. At any rate, Jonathan gave no credence to Demetrius I's promises (1 Macc 10:46). See (Goldstein 1983, pp. 410-11).

54 See (Barag 1994; Finkielsztejn 1998; Magen 2007, p. 193, no. 43). 
According to Josephus, Hyrcanus first took the Transjordanian cities of Madaba and Samaga (together with neighboring places). He then attacked Shechem and Gerizim, subduing "the nation of the Cutheans who dwelt round about that temple which was built in imitation of the temple at Jerusalem" (BJ 1.62). ${ }^{55}$ The account in Ant. (13.255) describes the destruction of the temple on Mt. Gerizim in more detail:

[Hyrcanus took] Shechem and Garizein and the Cuthaean nation, which lives near the temple built after the model of the sanctuary at Jerusalem, which Alexander permitted their governor Sanaballetes to build for the sake of his son-in-law Manasses, the brother of the high priest Jaddua as we have related before. Now it was two hundred years later that this temple was laid waste. ${ }^{56}$

After this, Hyrcanus moved southwards to Idumea and conquered Adora, Marisa, and other cities. Eventually, he subdued the Hellenistic city of Samaria. ${ }^{57}$

The results of recent archaeological investigations have confirmed Josephus' data. Excavations at Tell Balâtah (ancient Shechem) have shown that the site ceased to be inhabited in the late second century BCE. The destruction of Shechem goes back to $107 \mathrm{BCE}$ according to G. Ernest Wright, ${ }^{58}$ and to the year 112-111 BCE according to Dan Barag. ${ }^{59}$ Yitzhak Magen's excavations on top of Mt. Gerizim have revealed that John Hyrcanus not only destroyed the Samaritan temple but also devastated the surrounding city, in around 111-110 BCE. ${ }^{60}$ Magen has inferred from the discovery of a hoard of Hasmonean coins on the western side of the city that a Hasmonean garrison was subsequently based on top of the mount, to prevent the Samaritans from returning. ${ }^{61}$ A further likely reference to the destruction of the Samaritan temple by John Hyrcanus is found in Megillat Ta'anit, ${ }^{62}$ celebrating "the day of Mount Gerizim (יום הר גריזים)" on 21 Kislev. ${ }^{63}$

Josephus does not specify what prompted Hyrcanus to destroy the Mt. Gerizim temple. As Seth Schwartz has observed, the devastation of this sanctuary is usually interpreted by modern historians as an act of hostility against the Samaritan community as a whole. ${ }^{64}$ Menahem Mor and others have concluded that the Samaritans were treated by Hyrcanus like "the Hellenistic cities in Eretz Israel which were burned to the ground and their population deported."65 Zeev Safrai thinks that John Hyrcanus' treatment of the Samaritans was even harsher than that of the Hellenistic cities, for whereas the Hasmoneans later resettled cities like Samaria, they left Shechem abandoned. ${ }^{66}$ Likewise, according to Magen, "John Hyrcanus' decision to burn the city testifies to a wish for revenge, reflecting the great hatred which Jews harbored toward the Samaritans and their temple on Mt. Gerizim ... , as expressed in the words of Ben Sira ... (50:26)." ${ }^{\prime \prime 7}$ James D. Purvis sees religious and political factors behind the destruction of the Samaritan temple, whose aim would have been to "solidify the extent of Judaean authority" and hold strongly to the "inheritance of our fathers" (1 Macc 15:33-34). ${ }^{68}$ Seth Schwartz, for his part has proposed that in the wake of the persecution by Antiochus IV (167 BCE), the reformist

the term Cuthean, see e.g., (Schiffman 1993).

Trans. Marcus (Trans. Ralph Marcus (LCL 365; 1943, pp. 355-57).

BJ 1.64-65; Ant. 13.275-81.

See inter alia (Wright 1962, p. 358; 1965, p. 47; Campbell 2002, pp. 1, 8).

(Barag 1994, pp. 7-8).

(Magen 2007, p. 193; 2008b, p. 98).

(Magen et al. 2004, pp. 12-13; Magen 2008b, p. 81).

2 Megillat Ta'anit (Scroll of Fasting) is a treatise originating in the late Second Temple period; it lists thirty-five festival days on which fasting was forbidden, many of which were commemorations of victories of the Hasmonaean period. See (Noam 2003).

63 See: (Noam 2003, pp. 262-65).

64 (Schwartz 1993, p. 11).

65 See e.g., (Mor 1989, p. 16; 2003, p. 125, 127; Giles 2008, p. 540).

66 (Safrai 1986, p. 129).

67 (Magen et al. 2004, p. 12).

68 (Purvis 1968, pp. 113-15). 
Hellenized Samaritans (the so-called "Sidonians that were in Shechem" mentioned in Ant 12.257-64) took control of the Mt. Gerizim temple (henceforth dedicated to Zeus). They remained in charge of the sanctuary until John Hyrcanus subdued them with the support of the conservative and law-abiding Samaritan party. ${ }^{69}$

In a study published in 2016, I proposed that John Hyrcanus' destruction of the Samaritan temple was not intended as an act of exclusion, but was, on the contrary, an act of forced incorporation of the Samaritans into the Hasmonean state ${ }^{70}$. It was an extreme but fully logical attempt to rally them to his authority as high priest of the Jerusalem Temple. In theory, nothing further was necessary for the Samaritans to be incorporated with the Jews, in contradistinction to the Idumeans, who had to submit to circumcision and the laws of Moses. In this respect, it is by no means unlikely that John Hyrcanus considered the Samaritans genuine Israelites, for as we have seen, 2 Macc. (5:22-23; 6:1-2) shows that, in the mid-to-late second century BCE, the Jews (or at least some of them) regarded the Samaritans as brethren. I further proposed that John Hyrcanus' policy was aimed at diverting the Samaritans not only from their sanctuary on Mt. Gerizim, but also from the priesthood associated with it. In fact, as mentioned above, as the Jerusalem Temple high priest, John Hyrcanus could expect to enhance his authority and make substantial economic gains, with the offerings and tithes that had formerly been sent to Mt. Gerizim henceforth being redirected to the Jerusalem Temple. In support of this proposition, it has been argued that while the gentiles under Hasmonean rule were driven from their homes ${ }^{71}$ or enslaved, ${ }^{72}$ the Samaritans were apparently allowed to remain on their lands. The results of at least three archaeological surveys of Samaria, and especially the areas surrounding Mount Gerizim, show that these areas did not witness major changes in the number of sites in the Roman period in comparison with the Hellenistic period. ${ }^{73}$

But, at any rate, whatever Hyrcanus' motivations were, it is plain that the destruction of their temple greatly enhanced the resentment and defiance of a part of the Samaritan people toward the leadership in Jerusalem and its priesthood; as such, it has often been described as the decisive cause of the parting of the ways between the Jewish and Samaritan communities. ${ }^{74}$ It should be added that very little is known about the Samaritans in general and the state of their relations with the Jews in particular during the latter part of the Hasmonean period, following the reign of John Hyrcanus (135/4-104 BCE). Unfortunately, our main source, Josephus, provides only very scanty information about this issue, leaving it to modern scholars to consider this specific question.

\section{The Production of the Samaritan Pentateuch}

The question of the production of a distinctive Samaritan Pentateuch (SP) is directly relevant to the present discussion, first because it is usually dated to the late Hasmonean period, and second because it is considered by some as having greatly contributed to the separation of Samaritans and Jews. ${ }^{75}$

This dating is founded mainly on the assumption that the SP is based on a text-type similar to several manuscripts from the late Hasmonean period discovered at Qumran. ${ }^{76}$ These texts share

(Schwartz 1993). Schwartz's proposition has been challenged by Hanan Eshel, on the basis that the religious decrees of persecution were abolished by Antiochus V Eupator (164-162 BCE; 2 Macc 11:22-25), decades before the time of John Hyrcanus; (Eshel 2012, p. 534).

70 (Bourgel 2016).

71 This was the case for at least some of the Idumeans; on this see for instance (Faust and Erlich 2008, pp. 10-18, 22).

72 This was the case for the inhabitants of the city of Samaria (BJ 1.65).

73 (Campbell 1991; Finkelstein et al. 1997, pp. 2:907-19, 2:953-54; Zertal 2004, p. 63). An important exception is the environs of the Hellenistic city of Samaria (the "Sebastiyeh section") which experienced a sharp fall in the number of settlements during the transition from the Hellenistic to the Roman period (Zertal 2004, p. 93).

74 See among others (Cross 1966, pp. 210-11; Purvis 1981, pp. 348-49; Mor 1989, p. 18; Freyne 1999, p. 52; Anderson and Giles 2002, p. 30).

75 See (Knoppers 2011, p. 507).

76 See e.g.,: 4QpaleoExodm, 4QExod-Levf, 4QNumb and 4QDeutn. About five percent of the Pentateuch texts from Qumran are categorized as so-called pre-Samaritan or harmonizing texts. See for instance (Anderson and Giles 2002, pp. 43-58). 
common characteristics with the SP like harmonization of contradictory passages, the content of certain accounts and linguistic features. While some scholars have labelled these manuscripts as Samaritan, ${ }^{77}$ or proto-Samaritan, ${ }^{78}$ most have opted for the wording pre-Samaritan. ${ }^{79}$ In the late second to early first century BCE, or so it is widely assumed, the Samaritans added specific Samaritan readings to a previously existing harmonistic text-type, reflecting their ideology (such as the emphasis on the sanctity of Mount Gerizim ${ }^{80}$ to constitute their own version of the Pentateuch. ${ }^{81}$

With some reason, this proposition has been questioned on the ground that none of the so-called pre-Samaritan texts found at Qumran exhibit specific SP readings characteristic of Samaritan beliefs; accordingly, these manuscripts cannot provide confirmation for the shaping of the SP in the late Hasmonean period, which remains no more than a possibility. ${ }^{82}$

If, in spite of this, we were to accept with the majority of scholars that the SP took shape in the late second to early first century $\mathrm{BCE}$, there is still a further important question that needs to be asked: what impact did it have on relations between Gerizim and Jerusalem worshippers? Thus, while James D. Purvis has emphasized the importance of the promulgation of the SP in the Samaritan process of self-definition, ${ }^{83}$ other scholars have downplayed its implications, stressing that the late Second Temple period was still a time of textual fluidity and pluriformity. Thus, according to Judith E. Sanderson, the very fact that the SP is based on one of the popular text-types in circulation in the late Hasmonean period indicates that the Samaritans developed their holy writings "in concert with the religion and sacred writings of other Israelites." ${ }^{\prime 84}$

Stefan Schorch has identified two further interrelated phenomena closely connected to the emergence of the SP that contributed, he believes, to the shaping of Samaritan identity and the parting of the ways between Samaritan and Jews in the late second century BCE: ${ }^{85}$ first, the emergence of Samaritan Hebrew as a "group-specific sociolect," functioning as a linguistic marker of Samaritan identity. This proposition rests on the postulate that the dialect spoken by the forefathers of the Samaritans ceased to have any interaction with its linguistic surroundings by the late second to early first century BCE. Second, the constitution, then, of a Samaritan oral reading tradition, fixing the vocalization, pronunciation and phrasing of the consonantal framework of the Samaritan Pentateuch. This oral reading tradition was to become a means of identification for the Samaritan community and create a clear-cut distinction with the Jewish tradition. Schorch further contends that the written framework of the Samaritan Pentateuch and oral reading tradition "should be regarded as one linguistic corpus only, dating to the late 2nd century BCE." ${ }^{\prime 86}$ Although this proposition is appealing, it should be

77 See for instance (Baillet 1971).

78 See e.g., (Purvis 1968, p. 80; Tov 1989; 2012, pp. 74-92).

79 See inter alia (Crawford 2011; Tov 2013). Esther and Hanan Eshel have deemed it inappropriate to call the scrolls under discussion "pre-Samaritan" and "proto-Samaritan," for they do not include specifically Samaritan readings; they prefer to label them "harmonistic texts." See (Eshel and Eshel 2003, pp. 220-21). See also (Anderson and Giles 2012, pp. 34-35, no. 36).

80 Most illustrative in this respect is the Samaritan Tenth Commandment that emphasizes the sanctity of Mount Gerizim as God's chosen place of worship. It is composed of: Exod 13:11a, Deut 11:29b, 27:2b-3a, 4a, 5-7, and 11:30. For lists of other readings in the SP considered to be specific to the Samaritans, see inter alia (Margain 1991, cols. 767-68; Knoppers 2011, pp. 514-16). The specific Samaritan character of most these readings has recently been questioned by Edmond L. Gallagher (Gallagher 2015, pp. 99-101).

81 According to Esther and Hanan Eshel, the Samaritan ideological readings were added prior to the destruction of the temple on Mount Gerizim, (Eshel and Eshel 2003, pp. 238-39). See also, inter alia (Pummer 2007, p. 247; Anderson and Giles 2012, pp. 43, 49; Tov 1989; 2012, pp. 79, 90-93).

82 See for instance (Hjelm 2000, p. 93; Grabbe 2002, p. 214). Timothy Lim has proposed as an alternative possibility that the Samaritan Pentateuch emerged earlier in relation to the building of the Samaritan temple on Mount Gerizim; (Lim 2017, pp. 96, 102). See also (Gallagher 2015, pp. 103, 106).

83 (Purvis 1981, p. 333). See also (Dexinger 1992, p. 136).

84 (Sanderson 1986, p. 32). See also (Ulrich 1999, p. 65; Hjelm 2004, p. 15; Knoppers 2011, p. 527).

85 (Schorch 2005, pp. 11-15; Schorch 2013, pp. 135-50).

86 (Schorch 2007, p. 186). 
stressed that Schorch's early dating of the emergence of the Hebrew Samaritan has not been universally agreed on. ${ }^{87}$

\section{Literary Evidence for a Jewish Anti-Samaritan Polemic in the Hasmonean Period?}

Also closely tied to the question of the Samaritans in the Hasmonean period is the supposed anti-Samaritan polemic found in a number of second to first century Jewish writings, which has been interpreted as reflecting the growing rift between Jews and Samaritans at that time. Although it is beyond the scope of this study to thoroughly review these accounts, we shall give an overview of the current discussion on this complex issue. ${ }^{88}$ First, we shall briefly refer to the Greek version (G) of Sir $50,25-26$ which, as seen above, is probably to be dated to the years 132-117 BCE This reads:

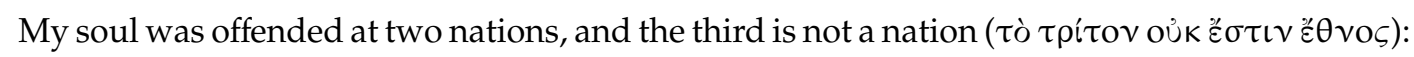

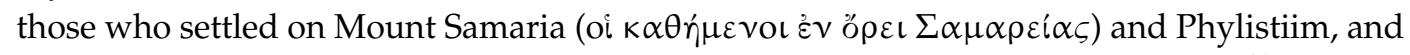

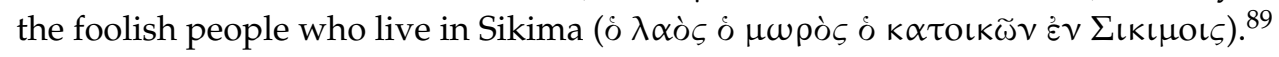

Strikingly enough, the expression appearing in the original Hebrew text "those who live on Mount Seir" has been replaced by "those who settled on Mount Samaria." While for some scholars, this change should be ascribed to a textual corruption in the Greek version, ${ }^{90}$ for others it is an intentional anti-Samaritan editing of the Hebrew text, reflecting the worsening of Jewish-Samaritan relations during the Hasmonean period. ${ }^{91}$ Thus, whereas the Idumeans (Seir) were considered fully-fledged Jews in the wake of their conversion by John Hyrcanus, the Samaritans became wholly alienated from the Jewish community. This interpretation is problematic in two ways. Firstly, it raises a chronological problem, for the conquest of Idumea by John Hyrcanus (112/111-108/107 BCE) occurred after the commonly accepted date for the translation of Ben Sira into Greek (between the years 132 and 117 BCE). Secondly, it requires supposing that Sir 50,25-26 (G) contains two self-contradictory references to the Samaritans, one to a "nation" and the second to a "non-nation." It is therefore obvious that "the foolish people that live in Shechem" are to be distinguished from "those who settled on Mount Samaria," who were most probably the inhabitants of the Hellenistic city of Samaria. ${ }^{92}$ The reference to the inhabitants of Shechem may contain an anti-Samaritan polemic, but, as in the original Hebrew text, this is no more than a mere possibility. A further possible explanation for calling them a non-people could stem from their being a mixed group..$^{93}$

Other anti-Samaritan polemics have been found in the numerous retellings of the rape of Dinah (Genesis 34) composed during the Hasmonean period. Interestingly enough, this episode was very popular and the focus of many interpretations in the second to first centuries BCE. Retellings of the rape of Dinah can be found in works like the Testament of Levi, the Book of Jubilees, the Book of Judith, Theodotus, and 4QNarrative and Poetic Composition. According to a widely accepted view, the authors of these texts reworked the story of Dinah's rape in order to create a correlation between the wicked Shechemites of Genesis 34 and the people who inhabited Shechem at their own time, that is supposedly the Samaritans. ${ }^{94}$

However, caution should be exercised in drawing too-general conclusions based on this premise: It should be stressed first that the great popularity of the biblical account of the rape of Dinah during

87 According to Moshe Florentin, Samaritan Hebrew postdates not only the Hebrew of the Dead Sea Scrolls, "but the Hebrew reflected in the good manuscripts of the Mishnah as well;" See (Florentin 2005, pp. 15-16).

88 This section is an abridged version of certain passages of my article: (Bourgel 2017).

89 Trans. (Pietersma and Wright 2007, p. 761).

90 (Smend 1906, p. 491).

91 See (Kartveit 2009a, p. 143; Schorch 2013, p. 137).

92 As Pummer has pointed out, ó $\rho \varepsilon \iota \Sigma \alpha \mu \alpha \rho \varepsilon\{\alpha \varsigma$ can refer either to the mountains in the area of Samaria in general, or to the mountain of the Hellenistic city of Samaria (Pummer 2009, p. 11).

93 (Tigchelaar 1996, p. 202, no. 77).

94 See, for instance (Collins 1980; Mendels 1987, p. 110). 
the Hasmonean period can be explained by reasons other than its geographical setting in Shechem. This episode indeed deals with questions that were of great concern to second-century BCE Jews, such as exogamous marriages and gentile conversions to Judaism..$^{95}$ Second, it is remarkable that certain adaptations of Genesis 34 omit to mention that the men of Shechem were circumcised before they were slaughtered by Shimeon and Levi (as described in Gen 34:24). ${ }^{96}$ Yet the representation of the Shechemites from Gen. 34 as permanently uncircumcised jeopardizes their identification with the second century BCE Samaritans, of whom there are no grounds for thinking that they had forsaken circumcision in the Hellenistic period. ${ }^{97}$ Unlike those accounts, the Testament of Levi does describe the circumcision of the Shechemites before they were slain (T. Levi 6,6). Furthermore, it creates a clear correlation between the past misdeeds of the Shechemites and the city of Shechem of his own time (T. Levi 7,1-3). T. Levi is part of the Testaments of the Twelve Patriarchs, a Greek Christian work from the late second century CE. However, it was almost certainly, in its original form, a Jewish text composed in the second century $\mathrm{BCE},{ }^{98}$ linked in some way with the Aramaic Levi fragments discovered in the Cairo Geniza and among the Dead Sea Scrolls. ${ }^{99}$ T. Levi 7 has often been seen as reflecting a second century BCE anti-Samaritan polemic. ${ }^{100}$ However, in this case too, care should be taken not to draw over-hasty conclusions, firstly since no parallel to T. Levi 7,1-3 has been found in the Aramaic Levi fragments; ${ }^{101}$ therefore one cannot say whether it belonged to the original Jewish strata of $\mathrm{T}$. Levi or to later Christian strata. Secondly, as already seen, not every reference to Shechem in ancient Jewish literature necessarily has to do with the Samaritans.

The case of the second century BCE writer Theodotus is also noteworthy. ${ }^{102}$ Theodotus is only known by a poem partially preserved by Eusebius of Caesarea (fourth century CE). Eusebius, however, was not quoting directly from the works of Theodotus but from the writings of the Greek historian Alexander Polyhistor (ca 105-35 BCE). ${ }^{103}$ The surviving section of Theodotus' poem deals with Dinah's rape. Scholarly discussion of this text has focused on his apparent merging of Jewish and Samaritan identity markers. Thus, for instance while on the one hand, Theodotus praises Shechem and depicts it

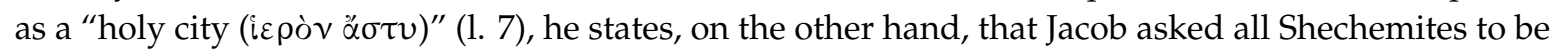

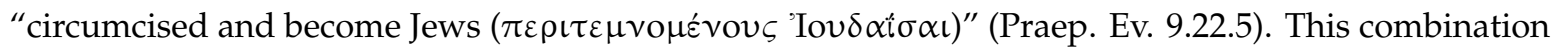
of Jewish and Samaritan features has been regarded as paradoxical and the result of textual corruptions probably to be ascribed to Alexander Polyhistor. Much of the scholarly debate has therefore centered on whether Theodotus was a Jew ${ }^{104}$ or a Samaritan, ${ }^{105}$ and on whether it was the Jewish or the Samaritan elements that were later appended to the original text. The terms of this discussion, though, may be based on a retro-projection of later conceptions of Jews and Samaritans as constituting fully separate and discrete categories. It is possible that Polyhistor faithfully reproduced Theodotus' poem, which in its original form contained both so-called Samaritan and Jewish characteristics. ${ }^{106}$

95 In this respect, it is obvious that the Book of Jubilees (30), has reworked Dinah's story in order to condemn marriages with foreigners and Gentiles' conversion to Judaism. See inter alia (Schwartz 1993, p. 12; Shatzman 2007, p. 260; Segal 2012, p. 349).

96 See for instance: Jubilees $(30,4)$ as well as the Book of Judith (9).

97 (Pummer 1982, pp. 185-86).

98 See, for instance (Charlesworth 1985, pp. 38-41).

99 On the link between the Aramaic Levi and the text in Greek of the Testament of Levi, see (DeJonge 1988).

100 See for instance (Collins 1980, p. 98; Kugel 1992, pp. 23-25).

101 The Aramaic Levi Document does contain a reworking of Genesis 34 (Greenfield et al., pp. 56-59); but as Kartveit has pointed out, this text is too fragmentary "to say anything about a certain ideological tendency in this material." (Kartveit 2009a, p. 175); sae also (Grabbe 2002, p. 207).

102 See (Fallon 1985a, p. 788).

103 Praep. Ev. 9.22.1-11 (GCS 43.1:512-516). On Alexander Polystor, see (Schmitz 1862, p. 115; Wacholder 1963, p. 83 no. 2).

104 See e.g., (Kippenberg 1971, p. 84; Collins 1980; Kartveit 2009a, pp. 122-40).

105 See e.g., (Freudenthal 1875, pp. 99-100; Bull 1967, p. 224; Purvis 1968, p. 13 no. 21; Wacholder 1972, p. 1102; Mendels 1987, p. 111).

106 Similar observations can be made about the mid-second century BCE writer commonly called Pseudo-Eupolemus. Eusebius' extensive excerpts from Alexander Polyhistor's work include a fragment on Abraham's life, from a work by the Jewish historian Eupolemus entitled “On the Jews"; Praep. Ev. 9.17.2-9 (GCS 43.1:502-504). Eupolemus is frequently identified with 
In contradistinction to the discussions of the above-mentioned works, there is a wide consensus among scholars that the Qumran text 4Q372 does reflect a polemic against the Samaritans and the Gerizim temple. ${ }^{107}$ This fragment contains a psalm attributed to Joseph, ${ }^{108}$ who, according to the prevailing view, is to be interpreted here not as the patriarch of Genesis, but as the Israelite northern tribes exiled from their homeland by the "nations" (4Q372 1, lines 4; 5; 7). Most remarkable are the new occupants of Joseph's territory who are called "fools" (נבלים) (4Q372 1, line 11) and "a hostile people (עם אויב) (4Q372 1, line 21), and are said to set up a "high place (במה) on a high mountain" (line 12) and speak "against the tent of Zion" (4Q372 1, line 13). Eileen Schuller was the first to see in this depiction a clear reference to the Samaritan community with its cultic center at Mount Gerizim. She has surmised that $4 \mathrm{Q} 372$ originally belonged to an anti-Samaritan work aiming at refuting the Samaritans' or "proto-Samaritans'" claim to descend from Joseph, by stating that his real offspring had remained in exile. ${ }^{109}$ Accordingly, we should interpret the high place erected on a high mountain in the land of Joseph as being a reference to the temple on Mount Gerizim, and the foolish people speaking against the tent of Zion as a reference to the Gerizim worshippers. Schuller has dated the composition of 4Q372 to before the destruction of the Gerizim temple at the hand of John Hyrcanus I (ca. 112/111 BCE) ${ }^{110}$ Reinhard Pummer, who sees Schuller's proposition as probable, has nonetheless rightly stressed that the invectives in 4Q372 could also be pointed against groups other than the Samaritans, such as "Shechemite reformers, or Greek colonists at Samaria, or no actual contemporary group at all."111 Having said that, Schuller's explanation remains the most likely. 4Q372 is also outstanding in that it acknowledges the existence of three discrete communities, that is, Israel, the gentiles and the Samaritans. In fact, the latter are not to be considered part of Israel or even as an unformed group of people, a non-people; rather, they exist as a constituted foe, and indeed a people. It should be noted though that 4Q372 1 (line 27) seems to consider the possibility of a "fool" repenting. ${ }^{112}$

By way of conclusion of this section, we can say that there is likely evidence for an anti-Samaritan polemic in second century BCE Jewish writings; however, this should not be exaggerated, for in many instances, one cannot be sure whether the Samaritans are actually intended.

\section{Samaritan Mikva'ot: Evidence for Judaization of the Samaritans in the Hasmonean Period?}

Another factor that may be relevant in this discussion and which has been raised by Yitzhak Magen is the discovery of mikva'ot (singular, mikveh) in ancient Samaritan settlements. The Jewish mikveh consisted of a stepped, plastered immersion pool cut into bedrock, and used to remove ritual impurity. It is generally accepted that it made its first appearance in the Hasmonean period, probably at some point between the second half of the second century and the first half of the first century

the envoy of Judas Maccabeus to Rome, who is referred to in 1 Macc 8,17 and 2 Macc 4,11; (Fallon 1985b). Jakob Freudenthal was the first to reject the attribution of the fragment to a Jewish writer because it says that Abraham was received as a guest at the city at the temple Argarizin, which is interpreted as "mountain of the Most High"; (Freudenthal 1875, pp. 85-87). Furthermore, Freudenthal saw such a depiction as incompatible with the laudatory representation of the Jerusalem Temple in other of Eupolemus' accounts. Accordingly, Freudenthal assigned this fragment to an unknown Samaritan author he called Pseudo-Eupolemus; henceforth, his proposition has been widely accepted. But as is the case with Theodotus, it may well be that discussions of Eupolemus are based on an anachronistic perception of Jews and Samaritans as already fully separate categories.

107 (Schuller). See also (Knibb 1992, p. 168; Kartveit 2009a, pp. 119-33; 2009b). For different opinions, see for instance (Kugler 2006, pp. 276-77; Mitchell 2009).

108 4Q372 is part of a Hebrew text known as 4QNarrative and Poetic Composition (or "Joseph Apocryphon"), that is contained in four more manuscripts (4Q371, 2Q22, 4Q373, and 4Q373a).

109 (Schuller, p. 371).

110 (Schuller, p. 376).

111 (Pummer 2009, p. 20); see also (Schwartz 1993, p. 22, no. 18).

112 According to Shuller, Joseph's commitment to teach God's law to "all who abandon" the Torah (1. 27), could be interpreted "more specifically and polemically in reference to the Samaritans" (Schuller, p. 366). If this is right, it would mean that the author of 4Q372 considered the Gerizim worshippers to be apostates who had forsaken God's law. 
BCE. ${ }^{113}$ Magen ${ }^{114}$ highlights several facts: First, mikva'ot have been found neither in the area of the sacred precinct of Mount Gerizim, nor in the remains of the adjacent second century BCE city; but many bathtubs were discovered on Mount Gerizim inside private houses from the Hellenistic period. Second, a number of mikva'ot were discovered elsewhere in Samaria, in different sites from the Roman and Byzantine periods (for example, Qedumim, El-Khirbe, Khirbet Samara, Horbat Migdal). Of special importance is one of the six mikva' ot unearthed in Qedumim (Mikveh A-1), which Magen dates to the "late second Temple period." 115 On this basis, Magen contends that the Samaritans made no use of mikva'ot until they were subdued by John Hyrcanus and their temple was destroyed at his hands. It was during the following decades that the custom of building mikva'ot was forced on them by the last Hasmonean rulers. ${ }^{116}$ If this proposition were true, it would be further evidence that John Hyrcanus and his successors did not seek to expel the Samaritans, but rather to forcibly integrate them into the Hasmonean state centered on Jewish Jerusalem. The plausibility of Magen's hypothesis, though, has been questioned on the ground that his early dating of Mikveh A-1 from Qedumim to the late Second Temple period is doubtful. ${ }^{117}$ Besides, the theory of coercion on the part of the Hasmoneans is only a hypothesis to explain the fact that mikva'ot came to be in use among the Samaritans at the latest during the Roman period; $; 18$ this could as well be explained by ongoing religious interaction and mutual influences between Jews and Samaritans in this period. ${ }^{119}$

\section{Conclusions}

The question of the Samaritans in the Hasmonean period is multifaceted and needs to be treated with different approaches. In the first place, the attitude of the Hasmoneans toward the Samaritans has turned out to be a more complicated issue than was initially assumed, and it may be reductive, if not erroneous, to simply see it as one of hatred and rejection. In my opinion, the Hasmonean rulers, as part of their general endeavor to religiously unite their new territorial acquisitions, sought to bring the Samaritans to recognize the Jerusalem temple as the only legitimate place of worship, and its priesthood as the only legitimate priesthood; while Jonathan used persuasion, John Hyrcanus, for his part, used coercion. However, their attempt eventually backfired and turned the Samaritans against them and the Jerusalem cult, the majority of the former remaining exclusively loyal to Mt. Gerizim. It should be added that the principles of this policy were abandoned a few decades later, when the Samaritans were expelled from the Jerusalem Temple in the days of the Roman procurator Coponius (6-9 CE; Ant 18:29-30 ${ }^{120}$ ).

At any rate, these events most likely further strengthened and accelerated the process of the formation of the Samaritans as a discrete community. It is difficult though to determine whether they had a direct effect on the composition of the Samaritan Pentateuch, which is often regarded either as a major factor in Samaritan identity constitution, or as the ultimate indicator of the emergence of the Samaritans as a group distinct from the Jews.

Another important issue is what the general Jewish understanding of the Samaritans was in the second century BCE. Remarkably enough, analysis of the relevant sources reveals that there were different opinions among Jews about the Samaritans. Thus, for instance, while 4Q372 1 reflects a feeling of estrangement towards the Samaritans to the point of seeing them as non-Israelites, 2 Macc. (5:22-23;

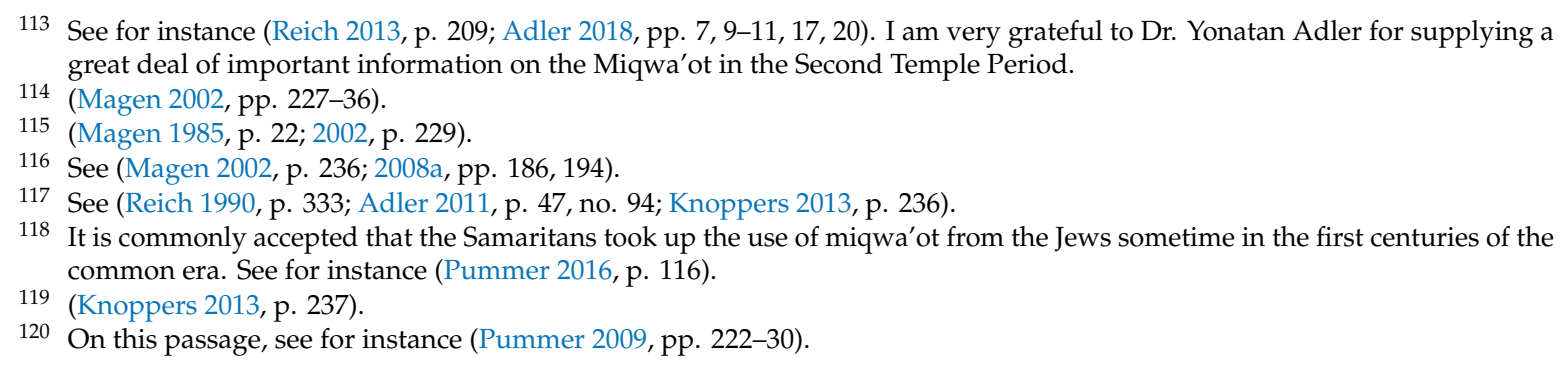


6:1-2) is evidence that during this period there were Jews who considered the Yahwistic worshippers in Gerizim to be a kind of Jews.

All in all, we know that the abovementioned historical developments and processes, which began during the Hasmonean period, had far-reaching implications on the emergence of the Samaritans as a self-contained community separate from the Jews. Their effects, however, were not as immediate and definitive as has been thought. In spite of periods of tension between Jews and Samaritans, there is evidence for ongoing religious and social relations between them during the following centuries. It is conspicuous in this respect that, at least until the late second century CE, the question of the Samaritans' status was still hotly debated and controversial among Jews. ${ }^{121}$

Funding: This research received no external funding.

Conflicts of Interest: The author declares no conflicts of interest.

\section{References}

Adler, Yonatan. 2011. The Archaeology of Purity: Archaeological Evidence for the Observance of Ritual Purity in Erez-Israel from the Hasmonean Period until the End of the Talmudic Era (164 BCE-400 CE). Ph.D. dissertation, Bar-Ilan University, Ramat Gan, Israel. (In Hebrew).

Adler, Yonatan. 2018. The Hellenistic Origins of Jewish Ritual Immersion. JJS 69: 1-29. [CrossRef]

Anderson, Robert T., and Terry Giles. 2002. The Keepers: An Introduction to the History and Culture of the Samaritans. Peabody: Hendrickson.

Anderson, Robert T., and Terry Giles. 2012. The Samaritan Pentateuch: An Introduction to Its Origin, History, and Significance for Biblical Studies. Atlanta: SBL.

Babota, Vasile. 2014. The Institution of the Hasmonean High Priesthood. SJSJ 165. Leiden and Boston: Brill.

Baillet, Maurice. 1971. Le texte Samaritain de l'Exode dans les manuscrits de Qumran. In Hommages à André Dupont-Sommer. Edited by André Dupont-Sommer, André Caquot and Marc Philonenko. Paris: Adrien-Maisonneuve, pp. 363-81.

Barag, Dan. 1994. New Evidence on the Foreign Policy of John Hyrcanus I. INJ 12: 1-12.

Bickermann, Elias. 1937. Un document relatif à la persécution d'Antiochos IV Épiphanes. RHR 115: 188-223.

Bourgel, Jonathan. 2016. The Destruction of the Samaritan Temple by John Hyrcanus: A Reconsideration. JBL 135: 505-23. [CrossRef]

Bourgel, Jonathan. 2017. Brethren or Strangers: Samaritans in the Eyes of Second Century BCE Jews. Biblica 98: $382-408$.

Bruneau, Phillipe. 1982. Les Israélites de Délos et la juiverie délienne. BCH 106: 465-504. [CrossRef]

Bull, Robert J. 1967. A Note on Theodotus' Description of Shechem. HTR 60: 221-28. [CrossRef]

Calduch-Benages, Núria. 2008. The Hymn to the Creation (Sir 42:15-43:33): A Polemic Text? In The Wisdom of Ben Sira: Studies on Tradition, Redaction, and Theology. Edited by Angelo Passaro and Giuseppe Bellia. DCLS 1. Berlin and New York: de Gruyter, pp. 119-38.

Campbell, Edward F., Jr. 1991. Shechem II: Portrait of a Hill Country Vale: The Shechem Regional Survey. Edited by Karen I. Summers. ASORAR 2. Atlanta: Scholars Press.

Campbell, Edward F. 2002. Shechem III: The Stratigraphy and Architecture of Shechem/Tell Balâtah. Boston: American Schools of Oriental Research.

Charlesworth, James H., ed. 1985. The Old Testament Pseudepigrapha and the New Testament: Prolegomena for the Study of Christian Origins. SNTSMS 54. Cambridge: Cambridge University Press.

Coggins, Richard J. 1975. Samaritans and Jews: The Origins of Samaritanism Reconsidered. Oxford: Basil Blackwel.

Coggins, Richard J. 1987. The Samaritans in Josephus. In Josephus, Judaism and Christianity. Edited by Louis H. Feldman and Gohei Hata. Detroit: Wayne State University Press, pp. 257-73.

Cohen, Shaye J. D. 1979. Josephus in Galilee and Rome: His Vita and Development as a Historian. Leiden: Brill.

Collins, John J. 1980. The Epic of Theodotus and the Hellenism of the Hasmoneans. HTR 73: 91-104. [CrossRef]

121 On this matter, see for instance (Hershkovitz 1940; Schiffman 1985). 
Crawford, Sidnie White. 2011. The Pentateuch as Found in the Pre-Samaritan Texts and 4QReworked Pentateuch. In Changes in Scripture: Rewriting and Interpreting Authoritative Traditions in the Second Temple Period. Edited by Hanne von Weissenberg, Juha Pakkala and Marko Marttila. BZAW 419. Berlin: De Gruyter, pp. 123-36.

Cross, Frank Moore, Jr. 1966. Aspects of Samaritan and Jewish History in Late Persian and Hellenistic Times. HTR 59: 201-11. [CrossRef]

Crown, Alan D. 1991. Redating the schism between the Judaeans and the Samaritans. JQR 86: 17-50. [CrossRef] de Hemmer Gudme, Anne Katrine. 2013. Before the God in this Place for Good Remembrance: A Comparative Analysis of the Aramaic Votive Inscriptions from Mount Gerizim. BZAW 441. Berlin and Boston: De Gruyter.

DeJonge, Marinus. 1988. The Testament of Levi and Aramaic Levi. RevQ 13: 367-85.

Dexinger, Ferdinand. 1992. Der Ursprung der Samaritaner im Spiegel der fruhen Quellen. In Die Samaritaner. Edited by Ferdinand Dexinger and Reinhard Pummer. Wege der Forschung 604. Darmstadt: Wissenschaftliche Buchgesellschaft, pp. 67-140.

Doran, Robert. 1983. 2 Maccabees 6:2 and The Samaritan Question. HTR 76: 481-85. [CrossRef]

Doran, Robert. 2012. 2 Maccabees: A Critical Commentary. Minneapolis: Fortress Press.

Dušek, Jan. 2007. Les manuscrits araméens du Wadi Daliyeh et la Samarie vers 450-332 av. J.-C. CHANE 30. Leiden: Brill.

Dušek, Jan. 2012. Aramaic and Hebrew Inscriptions from Mt. Gerizim and Samaria between Antiochus III and Antiochus IV Epiphanes. CHANE 54. Leiden: Brill.

Egger, Rita. 1991. Josephus Flavius and the Samaritans. In Proceedings of the First International Congress of the Société d'étude samaritaines. Edited by Abraham Tal and Moshe Florentin. Tel Aviv: Tel Aviv University Press, pp. 109-14.

Eshel, Hanan. 2012. The Growth of Belief in the Sanctity of Mount Gerizim. In A Teacher for All Generations: Essays in Honor of James C. VanderKam. Edited by Eric F. Mason. SJSJ 153/2. Leiden and Boston: Brill, pp. 509-35.

Eshel, Esther, and Hanan Eshel. 2003. Dating the Samaritan Pentateuch's Compilation in Light of the Qumran Biblical Scrolls. In Emanuel: Studies in Hebrew Bible, Septuagint, and Dead Sea Scrolls in Honor of Emanuel Tov. Edited by Shalom M. Paul, Robert A. Kraft, Lawrence H. Schiffman and Weston W. Fields. VTSup 94. Leiden and Boston: Brill, pp. 215-40.

Fallon, Francis T. 1985a. Theodotus (Second to First Century B.C.): A New Translation and Introduction. In Pseudepigrapha Volume 2: Expansions of the 'Old Testament' and Legends, Wisdom and Philosophical Literature, Prayers, Psalms, and Odes, Fragments of Lost Judeo-Hellenistic Works. Edited by James H. Charlesworth. London: Darton, Longman \& Todd, pp. 785-93.

Fallon, Francis T. 1985b. Eupolemus (Prior to First Century B.C.). In Pseudepigrapha Volume 2: Expansions of the 'Old Testament' and Legends, Wisdom and Philosophical Literature, Prayers, Psalms, and Odes, Fragments of Lost Judeo-Hellenistic Works. Edited by James H. Charlesworth. London: Darton, Longman \& Todd, pp. 861-72.

Faust, Abraham, and Adi Erlich. 2008. Hasmonean policy toward the gentile population in light of the excavations at Kh. er-Rasm and other rural sites. Jerusalem and Eretz Israel 6: 5-32. (In Hebrew).

Feldman, Louis H. 1996. Josephus' attitude toward the Samaritans: A Study in Ambivalence. In Studies in Hellenistic Judaism. Edited by Louis H. Feldman. AGJU 40. Leiden: Brill, pp. 114-36.

Finkelstein, Israel, Zvi Lederman, and Shlomo Bunimovitz, eds. 1997. Highlands of Many Cultures: The Southern Samaria Survey. 2 vols. Tel Aviv: Institute of Archaeology of Tel Aviv Publications Section.

Finkielsztejn, Gerald. 1998. More evidence on John Hyrcanus I's conquest: Lead Weights and Rhodian Amphora stamps. BAIAS 16: 33-63.

Florentin, Moshe. 2005. Late Samaritan Hebrew: A Linguistic Analysis of its Different Types. SSLL 43. Leiden: Brill.

Freudenthal, Jacob. 1875. Alexander Polyhistor und die von ihm erhaltenen Reste judäischer und Samaritanischer Geschichtswerke. Hellenistische Studien $1+2$. Breslau: Skutsch.

Freyne, Sean. 1999. Behind the Names: Galileans, Samaritans, Ioudaioi. In Galilee through the Centuries: Confluence of Cultures. Edited by Eric M. Meyers. Duke Judaic studies series 1; Winona Lake, Indiana: Eisenbrauns.

Gallagher, Edmond L. 2015. Is the Samaritan Pentateuch a Sectarian Text? ZAW 127: 96-107. [CrossRef]

Gilbert, Maurice. 2008. Methodological and Hermeneutical Trends in Modern Exegesis on the Book of Ben Sira. In The Wisdom of Ben Sira: Studies on Tradition, Redaction, and Theology. Edited by Angelo Passaro and Giuseppe Bellia. DCLS 1. Berlin and New York: de Gruyter, pp. 1-20.

Giles, Terry. 2008. The Samaritans in the Time of Jesus. In Encyclopedia of the Historical Jesus. Edited by Craig Evans. New York: Routledge, pp. 539-42. 
Goldstein, Jonathan A. 1983. II Maccabees. AncB 41A. Garden City: Doubleday.

Grabbe, Lester L. 2002. Betwixt and Between: The Samaritans in the Hasmonean period. In Second Temple Studies III: Studies in Politics, Class and Material Culture. Edited by Philip R. Davies and John Halligan. JSOTSup 340. Sheffield: Sheffield Academic Press, pp. 202-17.

Greenfield, Jonas C., Michael E. Stone, and Esther Eshel. The Aramaic Levi Document: Edition, Translation, Commentary. SVTP 19. Leiden: Brill, pp. 56-109.

Hall, Bruce W. 1987. Samaritan Religion from John Hyrcanus to Baba Rabba. Sydney: Mandelbaum Trust and University of Sydney.

Hanhart, Robert. 1982. Zu den ältesten Traditionen über das samaritanische Schisma. EI 16: 106-15.

Hershkovitz, Yehudah. 1940. The Samaritans in tannaitic literature. Yavneh 2: 71-105. (In Hebrew).

Hjelm, Ingrid. 2000. The Samaritans and Early Judaism: A Literary Analysis. JSOTSup 303. CIS 7. Sheffield: Sheffield Academic Press.

Hjelm, Ingrid. 2004. What Do Samaritans and Jews Have in Common? Recent Trends in Samaritan Studies. CBR 3: 9-59. [CrossRef]

Isaac, Benjamin. 1991. A Seleucid Inscription from Jamnia-on-the-Sea: Antiochus V Eupator and the Sidonians. IEJ 41: 142-43.

Isser, Stanley J. 1976. The Dositheans: A Samaritan Sect in Late Antiquity. Leiden: Brill.

Kartveit, Magnar. 2009a. The Origin of the Samaritans. VTS 128. Leiden: Brill.

Kartveit, Magnar. 2009b. Who Are the 'Fools' in 4QNarrative and Poetic Compositiona-c? In Northern Lights on the Dead Sea Scrolls: Proceedings of the Nordic Qumran Network 2003-2006. Edited by Anders Klostergaard-Petersen, Torleif Elgvin, Cecilia Wassen, Hanne von Weissenberg, Mikael Winninge and Martin Ehrensvärd. STDJ 80. Leiden and Boston: Brill, pp. 119-33.

Kartveit, Magnar. 2014. Samaritan Self-Consciousness in the First Half of the Second Century B.C.E. JSJ 45: 449-70. [CrossRef]

Kippenberg, Hans G. 1971. Garizim und Synagoge. Traditionsgeschichtliche Untersuchungen zur samaritanischen Religion der aramäischen Periode. Religionsgeschichtliche Versuche und Vorarbeiten, Bd. XXX. New York and Berlin: W. de Gruyter.

Knibb, Michael A. 1992. A Note on 4Q372 and 4Q390. In The Scriptures and the Scrolls. Studies in Honour of A.S. van der Woude on the Occasion of His 65th Birthday. Edited by F. Garcia Martínez, A. Hilhorst and C. J. Labuschagne. VT.S 49. Leiden: Brill, pp. 164-77.

Knoppers, Gary N. 2011. Parallel Torahs and Inner-Scriptural Interpretation: The Jewish and Samaritan Pentateuchs in Historical Perspective. In The Pentateuch: International Perspectives on Current Research. Edited by Thomas B. Dozeman, Konrad Schmid and Baruch J. Schwartz. FAT 78. Tübingen: Mohr-Siebeck, pp. 507-31.

Knoppers, Gary N. 2013. Jews and Samaritans: The Origins and History of Their Early Relations. Oxford: Oxford University Press.

Kraabel, A. Thomas. 1984. New Evidence of the Samaritan Diaspora Has Been Found on Delos. BA 47: 44-46. [CrossRef]

Kugel, James L. 1992. The Story of Dinah in the 'Testament of Levi. HTR 85: 1-34. [CrossRef]

Kugler, Robert A. 2006. Joseph at Qumran: The Importance of 4Q372 1 in Extending a Tradition. In Studies in the Hebrew Bible, Qumran and the Septuagint Presented to Eugene Ulrich. Edited by Peter Flint, Emanuel Tov and James C. VanderKam. VT.S 101. Leiden: Brill, pp. 261-78.

Lim, Timothy. 2017. The emergence of the Samaritan Pentateuch. In Reading the Bible in Ancient Traditions and Modern Editions: Studies in Textual and Reception History in Memory of Peter W. Flint. Edited by Andrew Perrin. EJL 47. Atlanta: Society of Biblical Literature, pp. 89-104.

Magen, Yitzhak. 1985. The miqwa'ot in Qedumim and the purification standards of the Samaritans. Cathedra 34: 15-26. (In Hebrew).

Magen, Yitzhak. 2002. The Samaritans during the Roman and Byzantine periods. In The Samaritans. Edited by Ephraim Stern and Hanan Eshel. Jerusalem: Yad Izhak Ben Tzvi, pp. 213-44. (In Hebrew)

Magen, Yitzhak. 2007. The Dating of the First Phase of the Samaritan Temple on Mount Gerizim. In Judah and the Judeans in the Fourth Century BCE. Edited by Oded Lipschitz, Gary Knoppers and Rainer Albertz. Winona Lake: Eisenbrauns, pp. 157-211. 
Magen, Yitzhak. 2008a. The Samaritans and the Good Samaritan. Translated by Edward Levin. Jerusalem: Staff Officer of Archaeology, Civil Administration for Judea and Samaria: Israel Antiquities Authority.

Magen, Yitzhak. 2008b. Mount Gerizim Excavations, vol. 2, A Temple City. JSP 8. Jerusalem: Staff Officer of Archaeology - Civil Administration of Judea and Samaria: Israel Antiquities Authority.

Magen, Yitzhak, Haggai Misgav, and Levana Tsfania. 2004. Mount Gerizim Excavations, vol. 1, The Aramaic, Hebrew $\mathcal{E}$ Samaritan Inscriptions. JSP 2. Jerusalem: Staff Officer of Archaeology, Civil Administration.

Magness, Jodi. 2001. The Cults of Isis and Kore at Samaria-Sebaste in the Hellenistic and Roman Periods. HTR 94: 157-77. [CrossRef]

Margain, Jean. 1991. Samaritain (Pentateuque). In Dictionnaire de la Bible. Edited by Jacques Briend. Supplément 11. Paris: Letouzey \& Ané, cols, pp. 762-773.

Marttila, Marko. 2012. Foreign Nations in the Wisdom of Ben Sira: A Jewish Sage between Opposition and Assimilation. DCLS 13. Berlin: de Gruyter.

Matassa, Lidia. 2007. Unravelling the Myth of the Synagogue on Delos. Bulletin of the Anglo-Israel Archaeological Society 25: 81-115.

Mazur, Belle D. 1935. Studies on Jewry in Greece. Athens: Printing Office Hestia.

Mendels, Doron. 1987. The Land of Israel as a Political Concept in Hasmonean Literature. TSAJ 15. Tübingen: Mohr Siebeck.

Mitchell, David C. 2009. A Dying and Rising Josephite Messiah in 4Q372. JSP 18: 181-205. [CrossRef]

Mor, Menahem. 1989. The Persian, Hellenistic and Hasmonean Period. In The Samaritans. Edited by Alan D. Crown. Tübingen: Mohr-Siebeck, pp. 1-18.

Mor, Menahem. 2003. From Samaria to Shechem: the Samaritan Community in Antiquity. Jerusalem: The Zalman Shazar Center. (In Hebrew)

Niese, Benedictus. 1900. Kritik der beiden Makkabäerbücher, nebst beiträgen zur Geschichte der Makkabäischen Erhebung. Hermes 35: 268-307.

Noam, Ver. 2003. Megillat Ta'anit: Versions, Interpretations, History. Jerusalem: Yad Izhak Ben-Zvi. (In Hebrew)

Oren, Eliezer D., and Uriel Rappaport. 1984. The Necropolis of Maresha-Beth Govrin. IEJ 34: 114-53.

Peters, John P., Hermann Thiersch, and Stanley Arthur Cook. 1905. Painted Tombs in the Necropolis of Marissa (Marēshah). London: Committee of the Palestine Exploration Fund.

Pietersma, Albert, and Benjamin G. Wright, eds. 2007. A New English Translation of the Septuagint and the Other Greek Translations Traditionally Included under That Title. New York: Oxford University Press.

Plassart, André. 1914. La Synagogue juive de Délos. RB 11: 523-34.

Pummer, Reinhard. 1982. Genesis 34 in Jewish Writings of the Hellenistic and Roman Periods. HTR 75: 177-88. [CrossRef]

Pummer, Reinhard. 2007. The Samaritans and their Pentateuch. In The Pentateuch as Torah: New Models for Understanding Its Promulgation and Acceptance. Edited by Gary N. Knoppers and Bernard M. Levinson. Eisenbrauns: Winona Lake, Ind., pp. 237-69.

Pummer, Reinhard. 2009. The Samaritans in Flavius Josephus. Tübingen: Mohr-Siebeck.

Pummer, Reinhard. 2016. The Samaritans: A Profile. Grand Rapids: Eerdmans.

Pummer, Reinhard. 2018. Samaritan Studies-Recent Research Results. In The Bible, Qumran, and the Samaritans. Edited by Magnar Kartveit and Gary N. Knoppers. Studia Samaritana 10. Berlin: de Gruyter, pp. 57-78.

Purvis, James D. 1965. Ben Sira and the Foolish People of Shechem. JNES 24: 88-94.

Purvis, James D. 1968. The Samaritan Pentateuch and the Origin of the Samaritan Sect. Cambridge: Harvard University Press.

Purvis, James D. 1981. The Samaritan Problem: A Case Study in Jewish Sectarianism in the Roman Era. In Traditions in Transformation: Turning Points in Biblical Faith. Edited by Baruch Halpem and John D. Levinson. Winona Lake: Eisenbrauns, pp. 323-50.

Rappaport, Uriel. 1990. The Sect of the Samaritans in the Hellenistic Period. Zion 55: 373-96. (In Hebrew).

Reich, Ronny. 1990. Miqwa'ot [Jewish ritual immersion baths] in the Land of Israel in the Second Temple and the Mishnah and Talmud Periods. Ph.D. dissertation, The Hebrew University, Jerusalem, Israel. (In Hebrew).

Reich, Ronny. 2013. Miqwa'ot_Jewish Ritual Baths_In the Second Temple, Mishnaic and Talmudic Periods. Jerusalem: Yad Yizhak Ben-Zvi and Israel Exploration Society. (In Hebrew)

Safrai, Zeev. 1986. The history of the settlement in Samaria in the Roman and Byzantine periods. In Shomron Studies. Edited by Zeev Safrai and Shimon Dar. Tel Aviv: Hakkibutz Hameukhad. (In Hebrew) 
Sanderson, Judith E. 1986. An Exodus Scroll from Qumran. 4QpaleoExodm and the Samaritan Tradition. HSS 30. Atlanta: Scholars Press.

Sauer, Georg. 2000. Jesus Sirach/Ben Sira. ATD Apokryphen 1. Göttingen: Vandenhoeck \& Ruprecht.

Schiffman, Lawrence H. 1985. Samaritans in Tannaitic Halakhah. JQR 75: 325-50. [CrossRef]

Schiffman, Lawrence H. 1993. Cuthaeans. In A Companion to Samaritan Studies. Edited by Alan D. Crown, Reinhard Pummer and Abraham Tal. Tübingen: Mohr-Siebeck, pp. 63-64.

Schmitz, Leonhard. 1862. Alexander Cornelius. In Dictionary of Greek and Roman Biography and Mythology. Edited by William Smith. New York: Harper and Brothers.

Schorch, Stefan. 2005. The Origin of the Samaritan community. Linguistic and Oriental Studies from Poznan 7: 7-16.

Schorch, Stefan. 2007. Spoken Hebrew in the Late Second Temple Period According to Oral and Written Samaritan Tradition. In Conservatism and Innovation in the Hebrew Language of the Hellenistic Period: Proceedings of a Fourth International Symposium on the Hebrew of the Dead Sea Scrolls E Ben Sira. Edited by Jan Joosten and Jean-Sebastien Rey. STDJ 73. Leiden: Brill, pp. 175-92.

Schorch, Stefan. 2013. The Construction of Samari(t)an Identity from the Inside and from the Outside. In Between Cooperation and Hostility: Multiple Identities in Ancient Judaism and the Interaction with Foreign Powers. Edited by Rainer Albertz and Jakob Wöhrle. JAJSup 11. Göttingen: Vandenhoeck \& Ruprecht, pp. 135-50.

Schuller, Eileen M. 1989-1990. 4Q372 1: A Text about Joseph. RevQ 14: 349-76.

Schwartz, Daniel R. 2008. 2 Maccabees. Berlin and New York: Walter de Gruyter.

Schwartz, Joshua J. 1991. Lod (Lydda), Israel: From its Origins Through the Byzantine Period, 560 BCE-640 C.E. BAR International Series 571. Oxford: Tempus Reparatum.

Schwartz, Seth. 1993. John Hyrcanus I's Destruction of the Gerizim Temple and Judaean-Samaritan Relations. Jewish History 7: 9-25. [CrossRef]

Segal, Michael. 2012. Rewriting the Story of Dinah and Schechem: The Literary Development of Jubilees 30. In The Hebrew Bible in Light of the Dead Sea Scrolls. Edited by Nora David, Kristin De Troyer and Shani Tzoref. FRLANT 239. Göttingen: Vandenhoeck und Ruprecht.

Shatzman, Israel. 2007. Jews and Gentiles from Judas Maccabaeus to John Hyrcanus According to Contemporary Jewish Sources. In Studies in Josephus and the Varieties of Ancient Judaism. Louis H. Feldman Jubilee Volume. Edited by Shaye J. D. Cohen and Joshua J. Schwartz. AJEC 67. Leiden: Brill, pp. 237-70.

Skehan, Patrick W., and Alexander A. DiLella. 1987. The Wisdom of Ben Sira: A New Translation with Notes. AB 39. New York: Doubleday.

Smend, Rudolf. 1906. Die Weisheit des Jesus Sirach erklärt. Berlin: Reimer.

Tigchelaar, Eibert J. C. 1996. Prophets of Old and the Day of the End: Zechariah, the Book of Watchers and Apocalyptic. OTSt 35. New York and Leiden: Brill.

Tov, Emmanuel. 1989. Proto-Samaritan Texts and the Samaritan Pentateuch. In The Samaritans. Edited by Alan D. Crown. Tübingen: Mohr-Siebeck, pp. 397-407.

Tov, Emmanuel. 2012. Textual Criticism of the Hebrew Bible. Third Edition Revised and Expanded. Minneapolis: Fortress.

Tov, Emmanuel. 2013. The Samaritan Pentateuch and the Dead Sea Scrolls: The Proximity of the Pre-Samaritan Qumran Scrolls to the SP. In Keter Shem Tov: Collected Essays on the Dead Sea Scrolls in Memory of Alan Crown. Edited by Shani Tzoref and Ian Young. Piscataway: Gorgias Press, pp. 59-88.

Trümper, Monika. 2004. The Oldest Original Synagogue Building in the Diaspora: The Delos Synagogue Reconsidered. Hesperia 73: 513-98. [CrossRef]

Ulrich, Eugene C. 1999. The Dead Sea Scrolls and the Origins of the Bible. Grand Rapids: Eerdmans.

Van der Horst, Pieter W. 2003. Anti-Samaritan Propaganda in Early Judaism. In Persuasion and Dissuasion in Early Christianity, Ancient Judaism and Hellenism. Edited by Pieter W. van der Horst, Maarten J. J. Menek, Joop F. M. Smit and Geert Van Oyen. CBET 33. Leuven: Peeters, pp. 25-44.

Vanderkam, James C. 2004. From Joshua to Caiaphas: High Priests after the Exile. Minneapolis: Fortress Press.

Wacholder, Ben-Zion. 1963. Pseudo-Eupolemus' two Greek Fragments on the Life of Abraham. HUCA 34: 83-113. Wacholder, Ben-Zion. 1972. Theodotus. EncJud 15: 1102.

White, L. Michael. 1987. The Delos Synagogue Revisited Recent Fieldwork in the Graeco-Roman Diaspora. HTR 80: 133-60. [CrossRef] 
Wright, G. Ernest. 1962. The Samaritans at Shechem. HTR 25: 357-66. [CrossRef]

Wright, G. Ernest. 1965. Shechem: The Biography of a Biblical City. New York: McGraw-Hill Book Company.

Zertal, Adam. 2004. The Manasseh Hill Country Survey, vol. 1, The Shechem Syncline. CHANE 21.1. Leiden: Brill.

(C) 2019 by the author. Licensee MDPI, Basel, Switzerland. This article is an open access article distributed under the terms and conditions of the Creative Commons Attribution (CC BY) license (http://creativecommons.org/licenses/by/4.0/). 